\title{
PAINEL
}

\section{do vasto sertão}

\section{Rubens Nlves Pereira}

Ensaio Fotográfico: Juraci Dórea

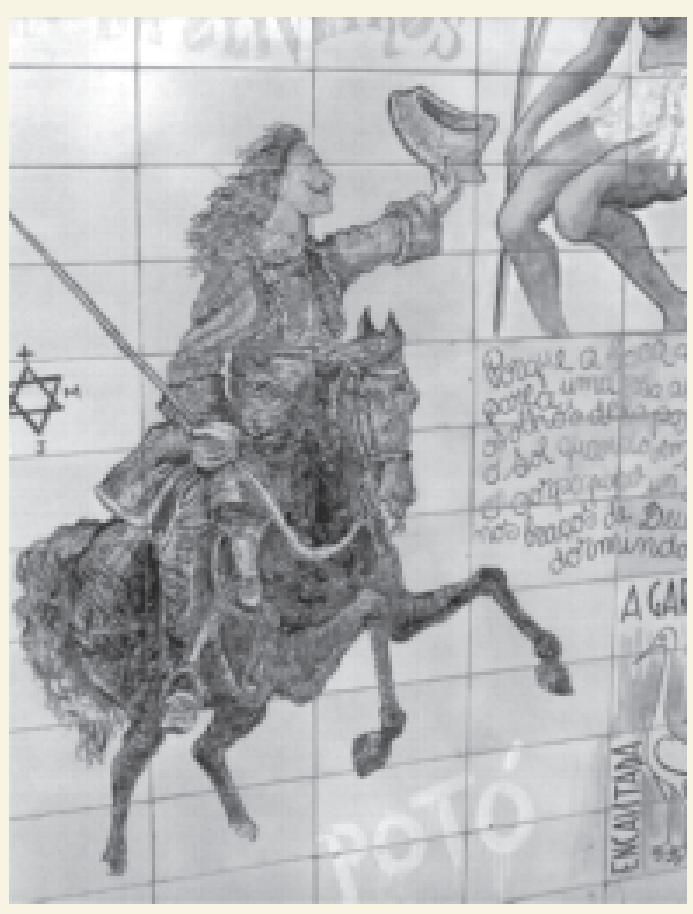

Em 10 de janeiro de 1977, por um decreto municipal, foi extinta a Feira-Livre que se estendia pela principal avenida, a Getúlio Vargas, e ruas e praças do centro de Feira de Santana, cidade que traz no nome e na própria origem a marca desse tradicional comércio de rua. Quando extinta, já se caracterizava como uma das maiores feiras livres do interior do Nordeste, atraindo milhares de pessoas da zona rural e das mais diversas cidades da região, com seus comerciantes, lavradores, vaqueiros, cordelistas, cantadores, biscateiros, donas-de-casa e um sem-número de tipos populares que faziam daquela grande feira um evento único não apenas em termos comerciais, como também na articulação de uma dinâmica sociocultural das mais ricas e complexas no universo popular. Lênio Braga, sensível a essa realidade, busca sobretudo no espírito da feira livre a variedade de tipos e textos, de tratos e trocas que irão alimentar os vastos registros culturais e os diversos regimes expressivos e simbólicos do seu mural. 


\section{PAINEL DE LÊNIO BRAGA Estórias da Feira \& Mural do Sertão}

Especialmente convidado para compor com a arquitetura moderna da nova Estação Rodoviária de Feira de Santana, Bahia, o artista plástico Lênio Braga inaugura, no ano cristão de 1967, um fabuloso painel da cultura popular nordestina, em forma de mural medindo nada menos que $120 \mathrm{~m}^{2}$, com superfície de azulejos que contou com a colaboração do ceramista Udo Knoff. Imponente por suas dimensões, o mural impressiona ainda pela diversidade temática, pela riqueza de detalhes e, sobretudo, pela beleza plástica das suas figurações. Pintor, escultor, ceramista, desenhista, gravador, muralista, designer gráfico e fotógrafo, Lênio Braga (1931-1973) era paranaense de Ribeirão Claro, tendo vivido na Bahia nas décadas de 50 e 60, onde produziu grande parte da sua obra.

No ensaio fotográfico disseminado pelas capas, orelhas e nas páginas que aqui se iniciam, especialmente produzido para este número inau- 
gural de Légua \& Meia, o fotógrafo Juraci Dórea, com suas credenciais de pintor, escultor, poeta e estudioso da cultura popular, procurou contemplar percepções diferenciadas do mural, com registros que vão do olhar panorâmico à fixação de detalhes, passando pelos crivos temáticos ou simbólicos. A idéia é dar ao leitor uma noção de conjunto e, ao mesmo tempo, apresentar-lhe os movimentos que fazem desse mural de Lênio Braga algo de extraordinário não só para Feira de Santana (que além de abrigar a obra tem muitas histórias contempladas no painel), como também para a arte e a cultura brasileiras em sua pluralidade. Articulando textos e imagens, narrando imagens-textos, o mural tem nos registros culturais e na plasticidade humana da feira-livre uma das suas forças motrizes. É nesse diapasão que emergem no painel de Lênio Braga contextos variados que dizem dos comércios de pássaros a mitos, que tratam da civilização do couro aos cordéis, que narram a devoção aos santos e as superstições, que ilustram a sedução da mídia e refletem as traduções da arte.

Esse painel, enfim, caracteriza-se ainda pela profusão de zonas e tonalidades expressivas: salientam-se as imagens líricas em contraponto a cenas dramáticas; ganha corpo um imaginário lúdico do sertanejo em seu que-fazer cotidiano de crenças e lutas; evoca-se uma memória afetiva que talha traços marcantes de seres e coisas do sertão. Lênio Braga, podemos concluir, alia em seu painel a imaginação caprichosa a uma consciência atenta, marcada pelos pequenos assombros do nosso dia-a-dia. 
A FEIRA LIVRE

Eram muitas e variadas as mercadorias que circulavam na feira livre de Feira de Santana. Eram muitas feiras, livres, dentro da mesma feira. Era um caos aparente que regulava comércios e conversas; um colorido das falas, de pássaros, de frutas. Eram infinitas pequenas coisas, e muitas gentes, misturadas na singularidade da feira.
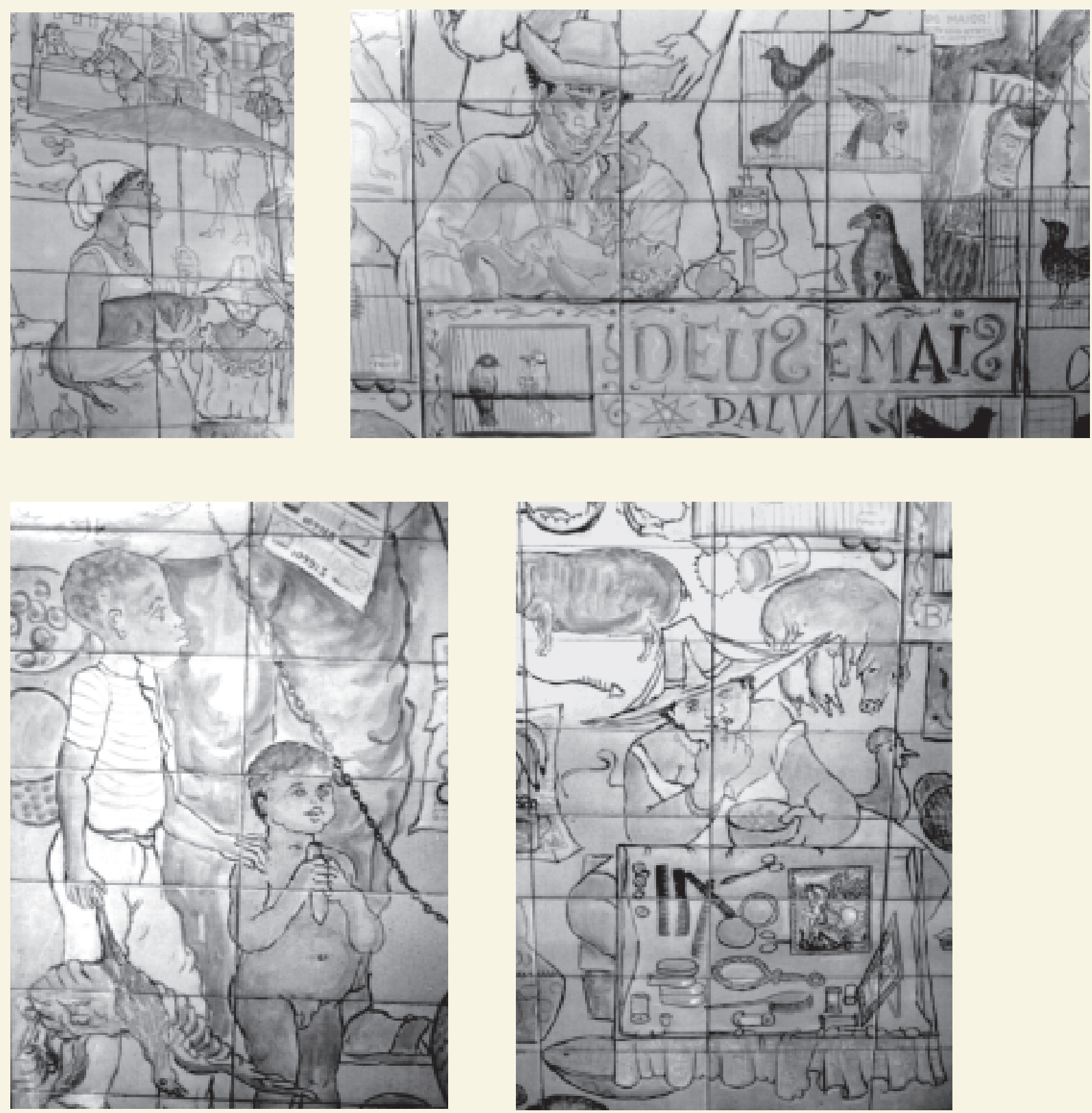

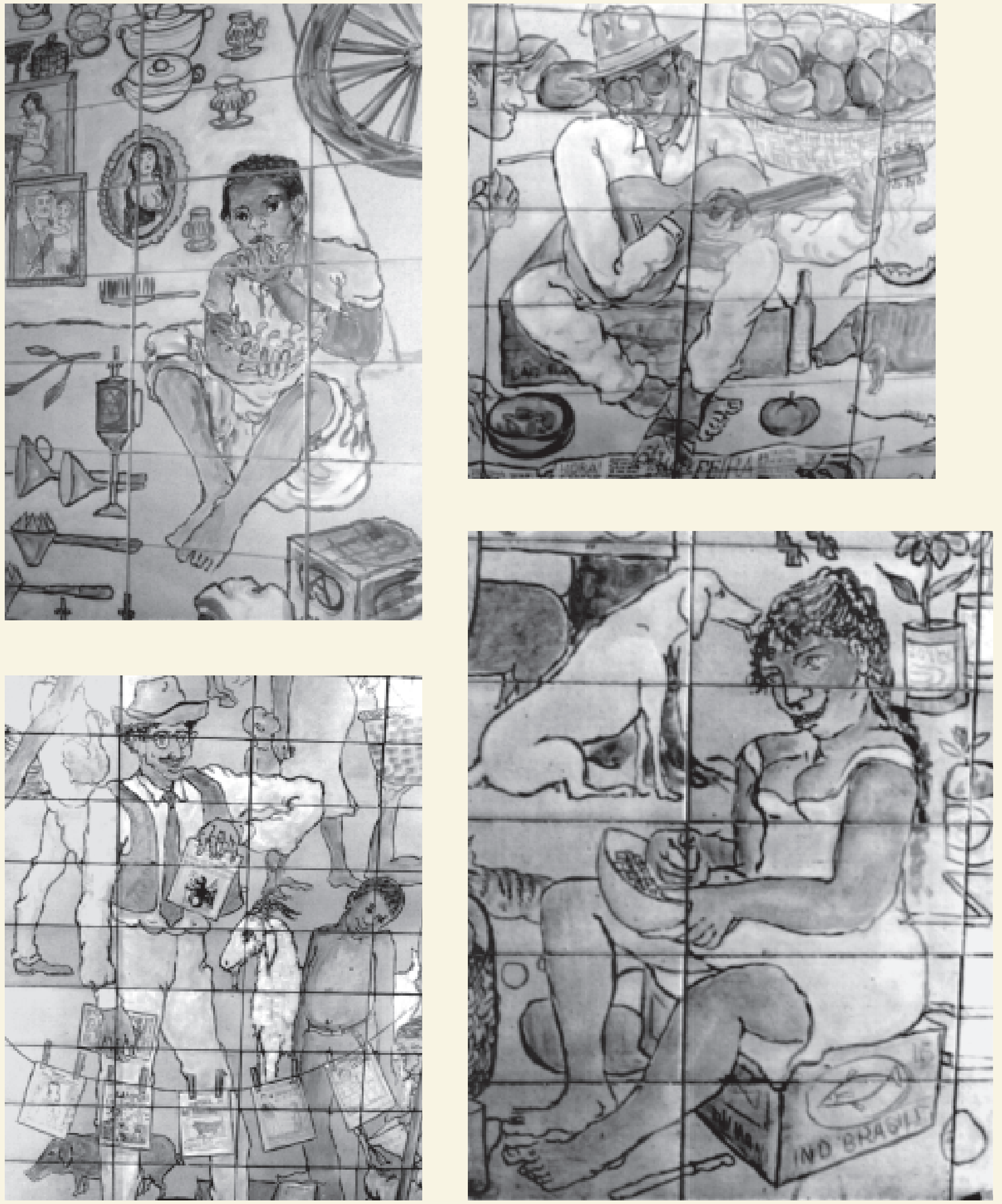


\section{CORDEL, A FEIRA LIVRE DA DOESIA}

A literatura de cordel, com sua abrangência temática e força poética, constitui-se em privilegiado ponto de convergência da cultural popular nordestina. Ela também vai ser presença explícita no painel de Lênio Braga, com seus temas míticos, históricos, fantásticos, burlescos, religiosos e quantos mais. "O bicho que está aparecendo em Feira de Santana”, história fantástica e assustadora que circulou na cidade a partir da década de 50, merece de Lênio Braga não só a pintura do tal bicho na capa de um dos folhetos de cordel que representa. O desenho do bicho que chegon a feira (Este veio a ser o título de um romance do escritor e crítico cultural feirense, há muito radicado no Rio de Janeiro, Muniz Sodré, publicado pela Editora Francisco Alves, em 1991) e a inscrição correspondente aparecem ainda de forma ampliada em meio a outras figuras do mural (ver a 4 capa), como a indicar que tudo ali não passa de um largo espaço de narrativas que confundem ficção e realidade, memória e imaginação. A feiralivre, como espaço privilegiado da circulação do cordel, é também uma grande metáfora da mobilidade temática e expressiva desse canto do povo, e do mural de Lênio.
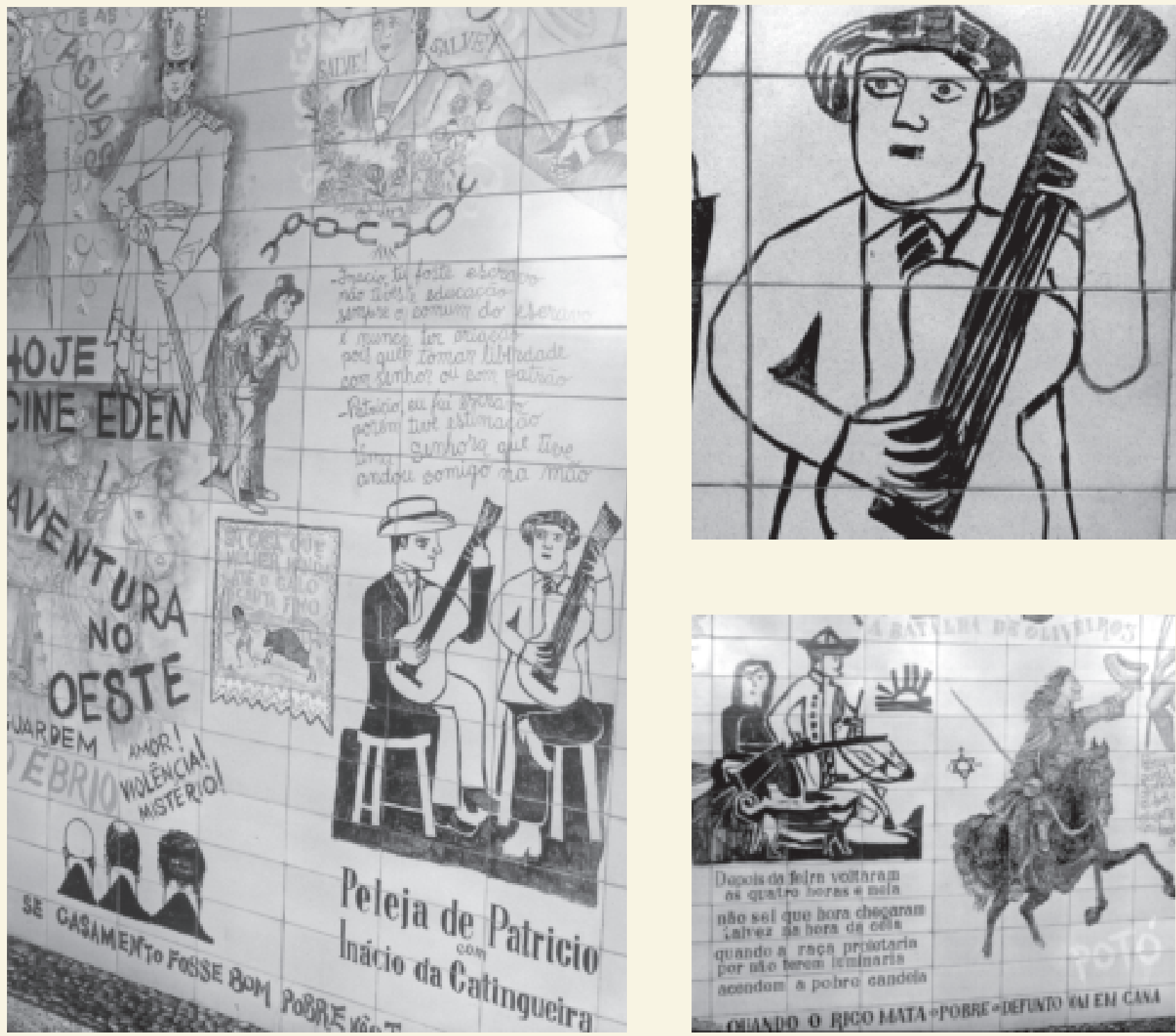


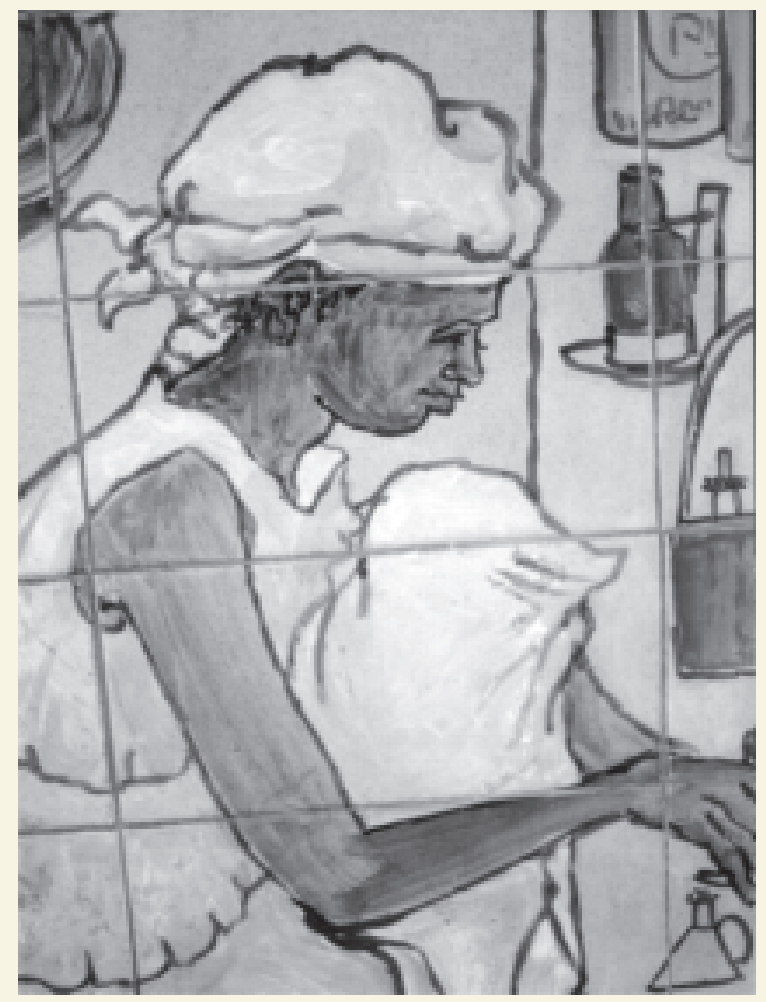

TRAÇOS E TIDOS DOPULARES

O olhar sensível e a mão habilidosa de Lênio Braga reservam ao espectador atento de seu painel a alegria de incontáveis descobertas, dentre elas a de figuras populares que fascinam pela simplicidade dos traços aliada à força expressiva dos corpos e das almas.
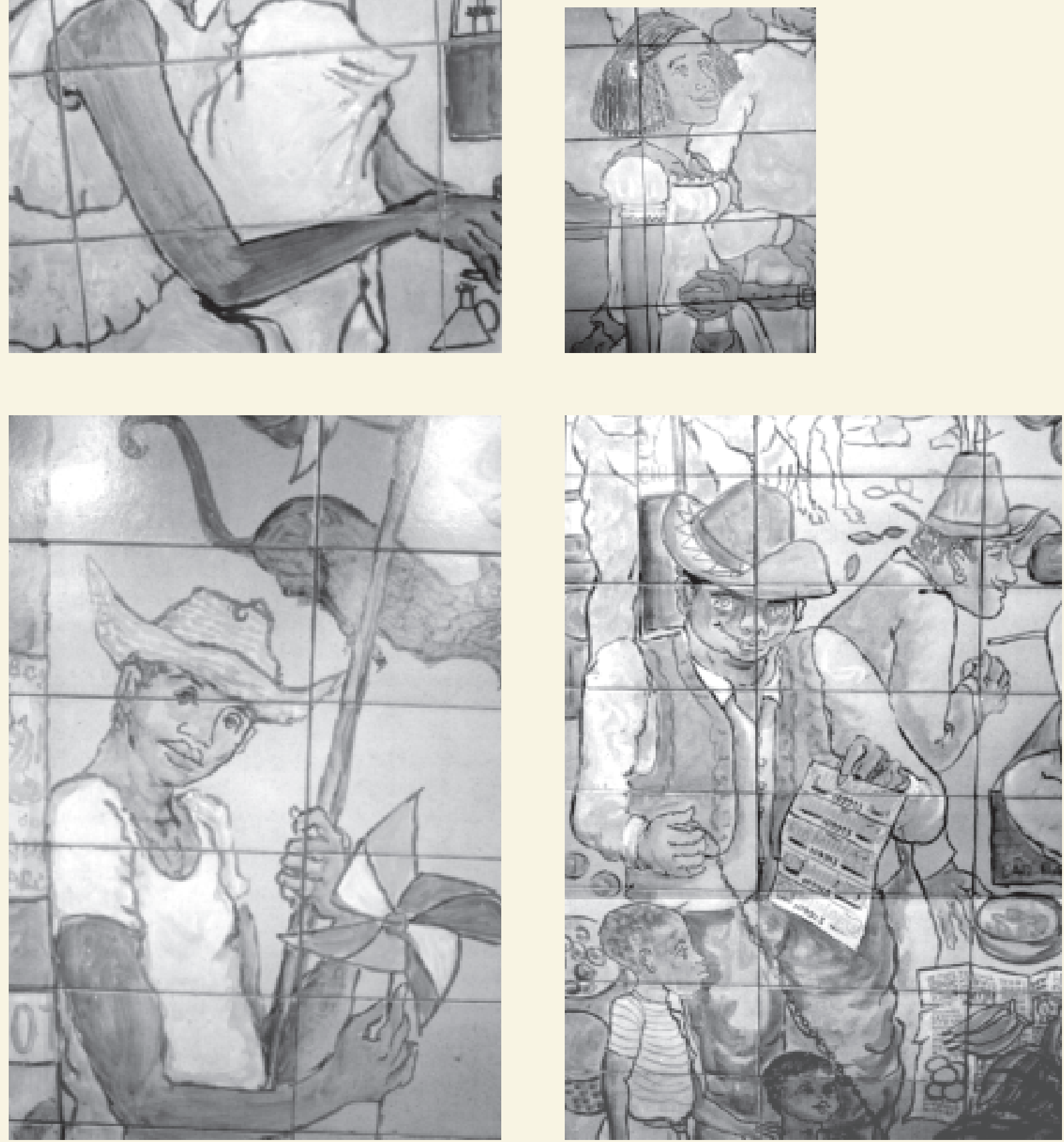
VAQUEIRO DE LAÇO E GIBĨO

Porta de entrada do sertão baiano, Feira de Santana, cidade cortada por três rodovias federais e considerada um dos maiores entroncamentos rodoviários do Brasil, teve no comércio de gado a sua origem e, até pouco tempo, a sua base de sustentação econômica. E, na figura do vaqueiro, um símbolo antropológico da sua identidade cultural. O painel de Lênio Braga privilegia essa emblemática figura do vaqueiro, que aparece envolta na força cultural de uma civilização do couro em seus equipamentos representada.

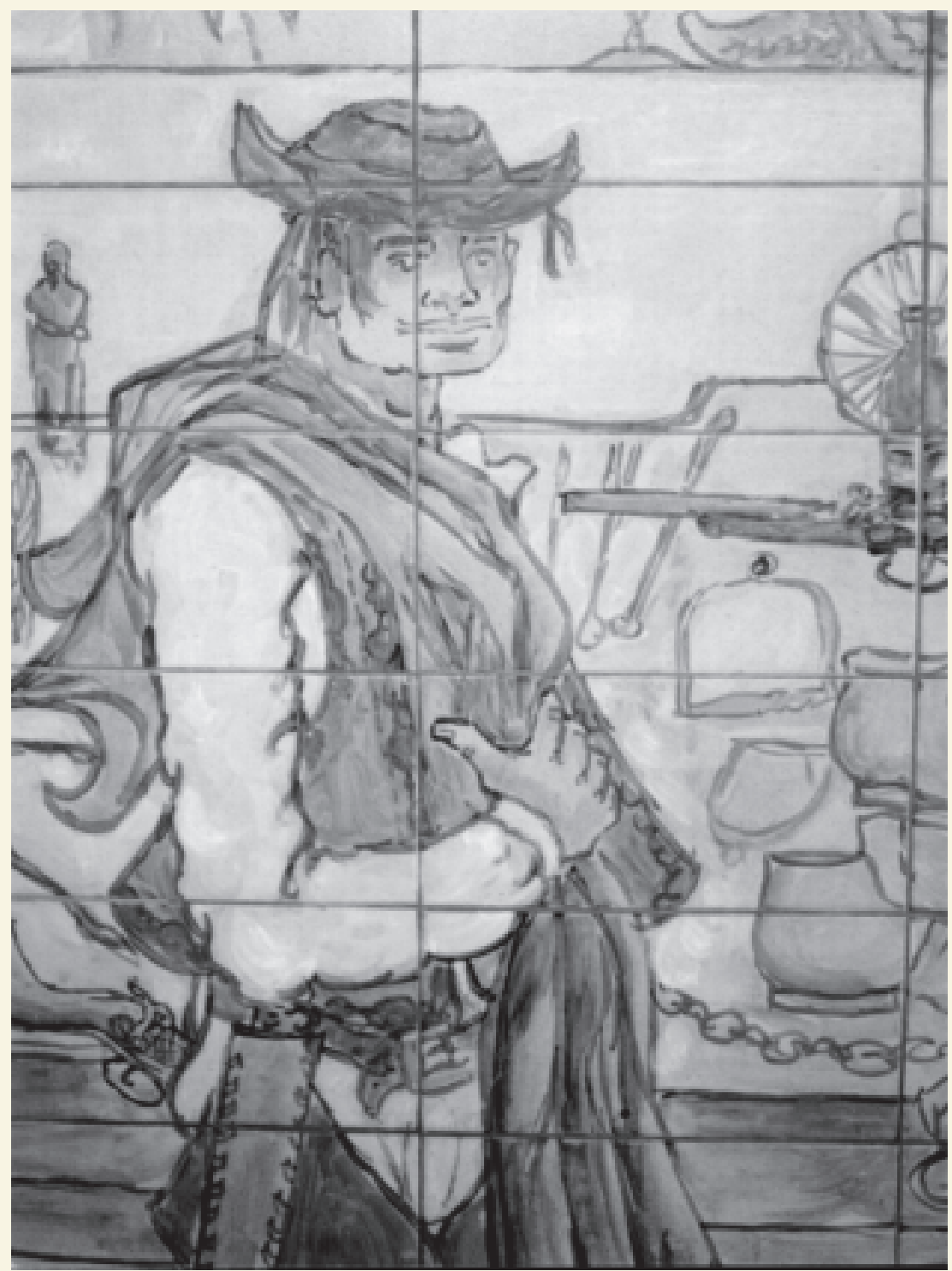

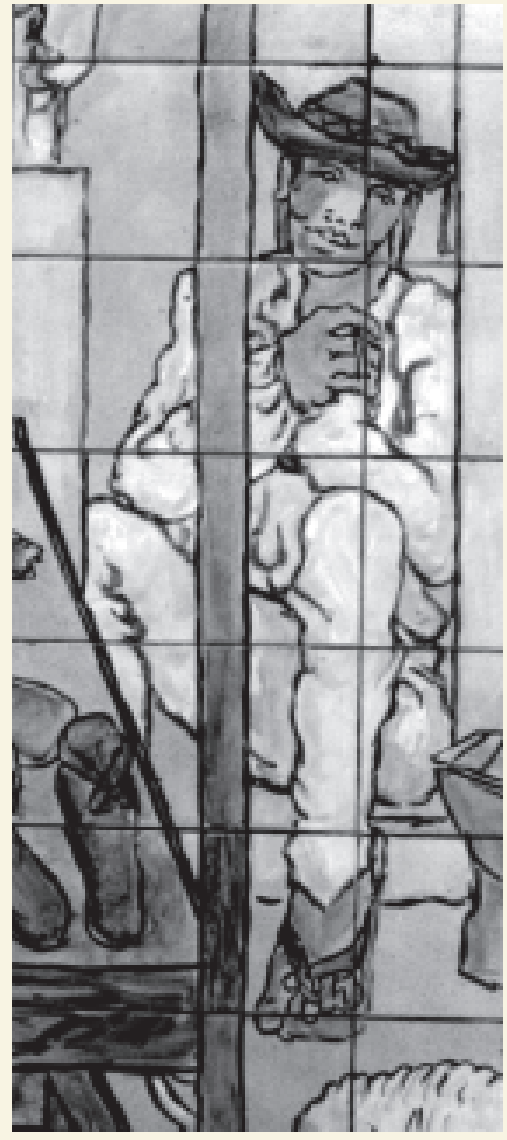

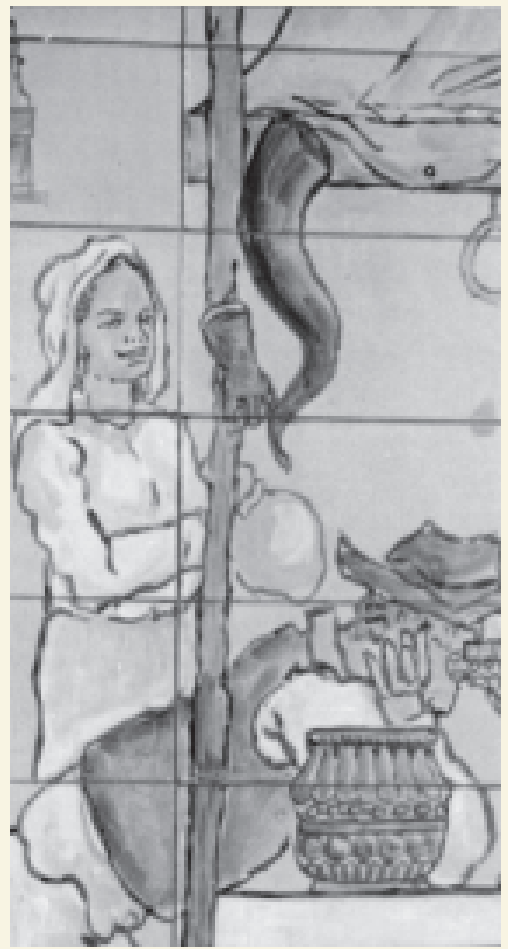




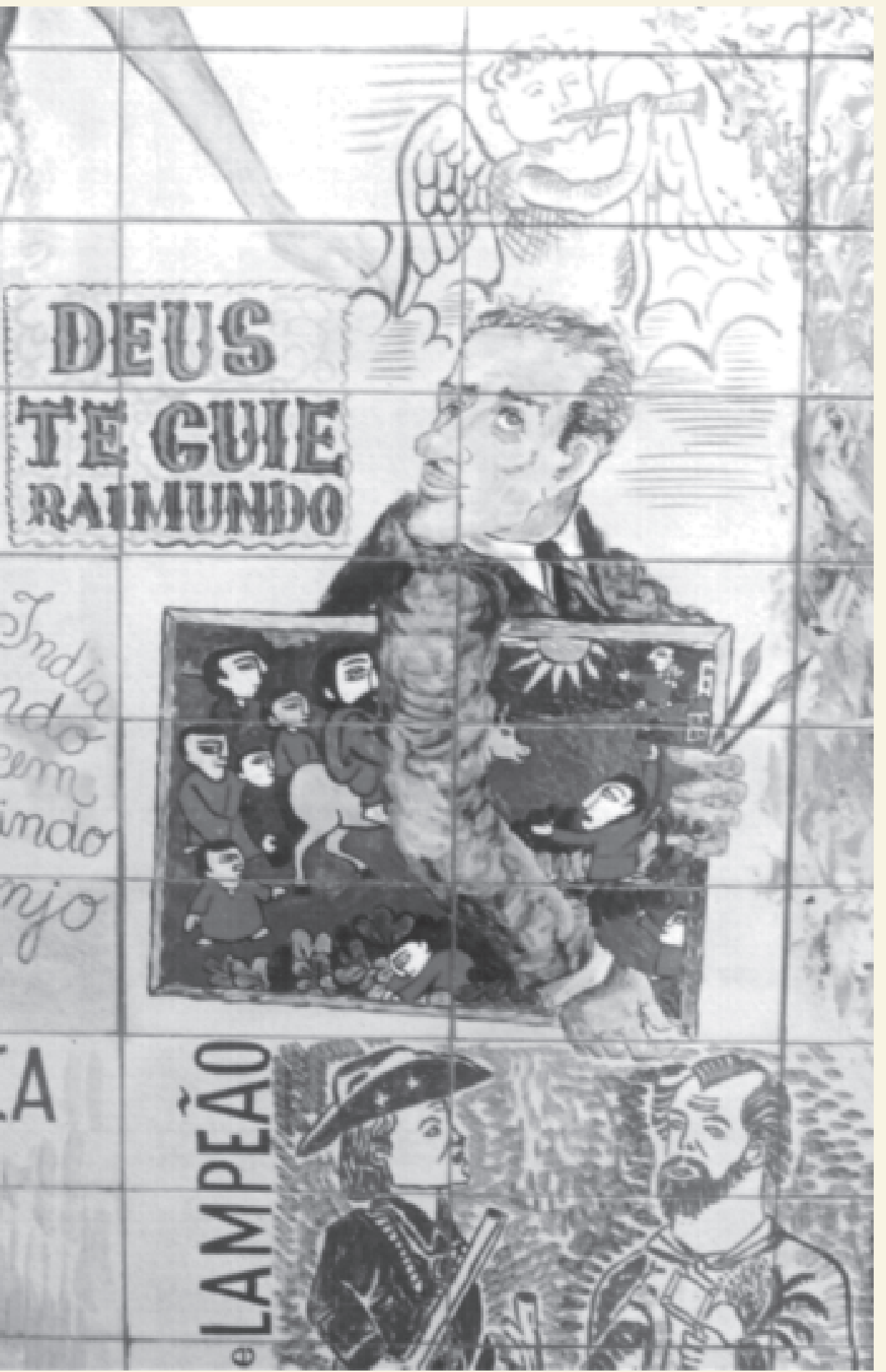

MUNDO, VASTO RAIMUNDO, NA TELA COMO NO CÉU

O artista plástico feirense Raimundo de Oliveira (1930-1966), internacionalmente reconhecido pelo valor da sua obra em que predomina o tema sacro, merece de Lênio Braga uma bela referência metapoética e uma saudação amiga.

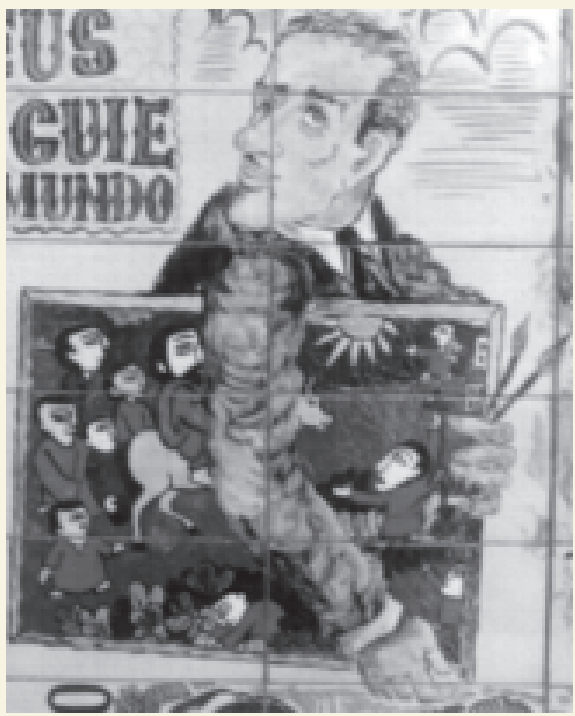




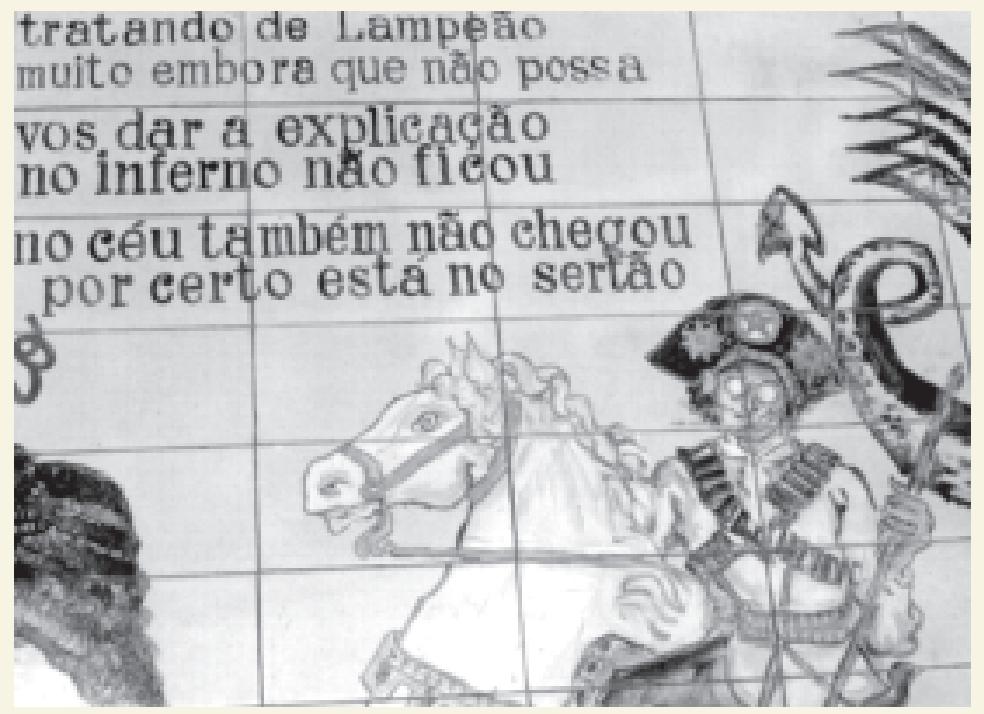

$\bigcirc$ TEMÍVEL-AMADO LAMDIÑO

Lampião, respeitado cangaceiro do sertão. Lampião, pelo sim e pelo não. Em prosa e verso, em gravura e viola-de-cantador, paramentado. Presença viva e das mais fortes no imaginário popular, Virgulino Ferreira, o Lampião, faz por merecer a sua fortuna no mural de Lênio Braga, onde aparece com distintivos de valente e destaques de mito: figura em capa e em versos de cordel; em assombros de guerra e morte sobre o cavalo; pelejando com mil demônios; confrontando com São Pedro.
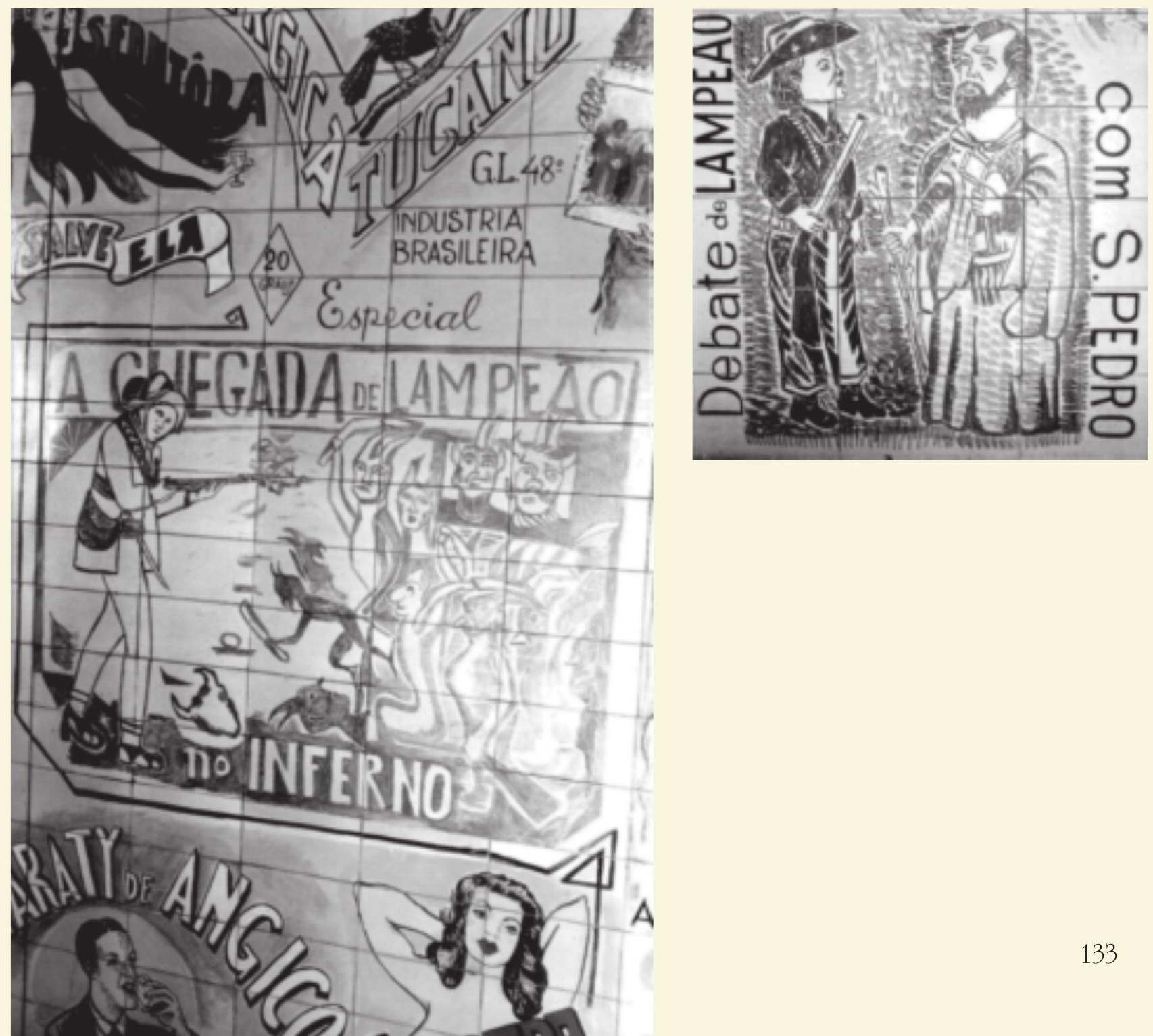


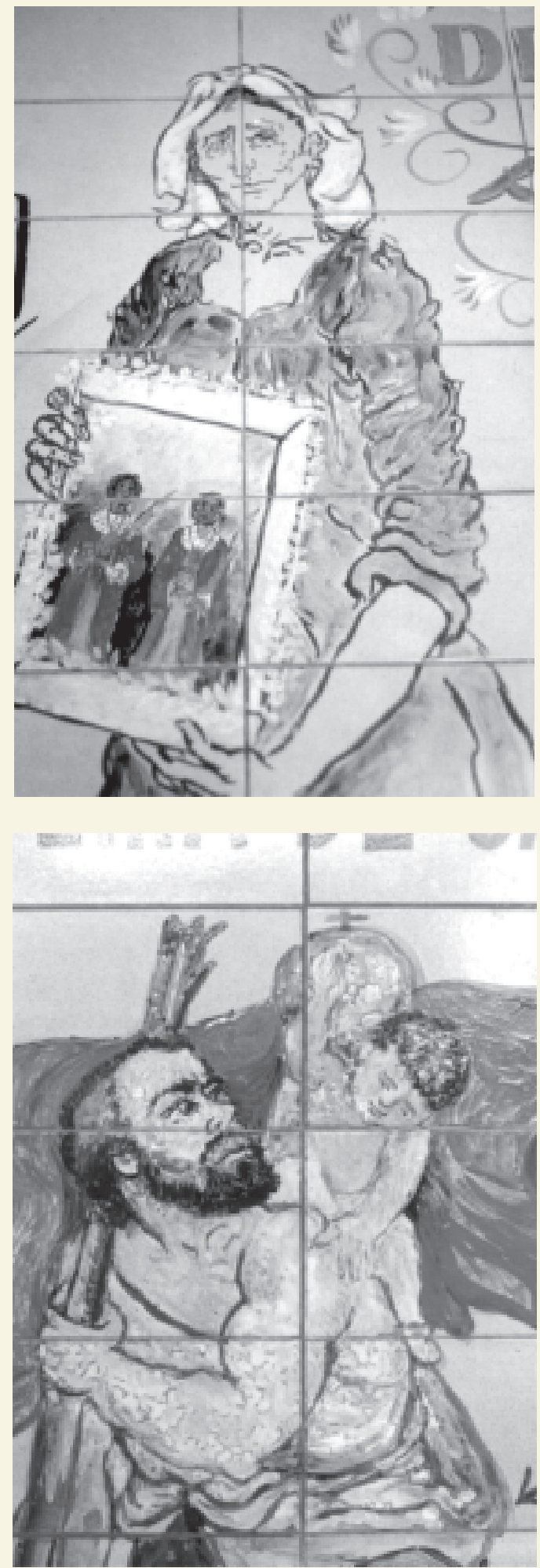

RELIGIOSIDADE DE MUITOS CREDOS

A religiosidade é uma dimensão humana das mais fortes para o sertanejo, cuja fé extrapola o dogma cristão em direção a formas sincréticas. Esse importante fato não passa despercebido ao muralista Lênio Braga. Entre muitas figuras de santos, beatos e objetos de devoção, destacam-se personagens como Antônio Conselheiro, São Cristóvão, São João e os meninos brincalhões Cosme e Damião.

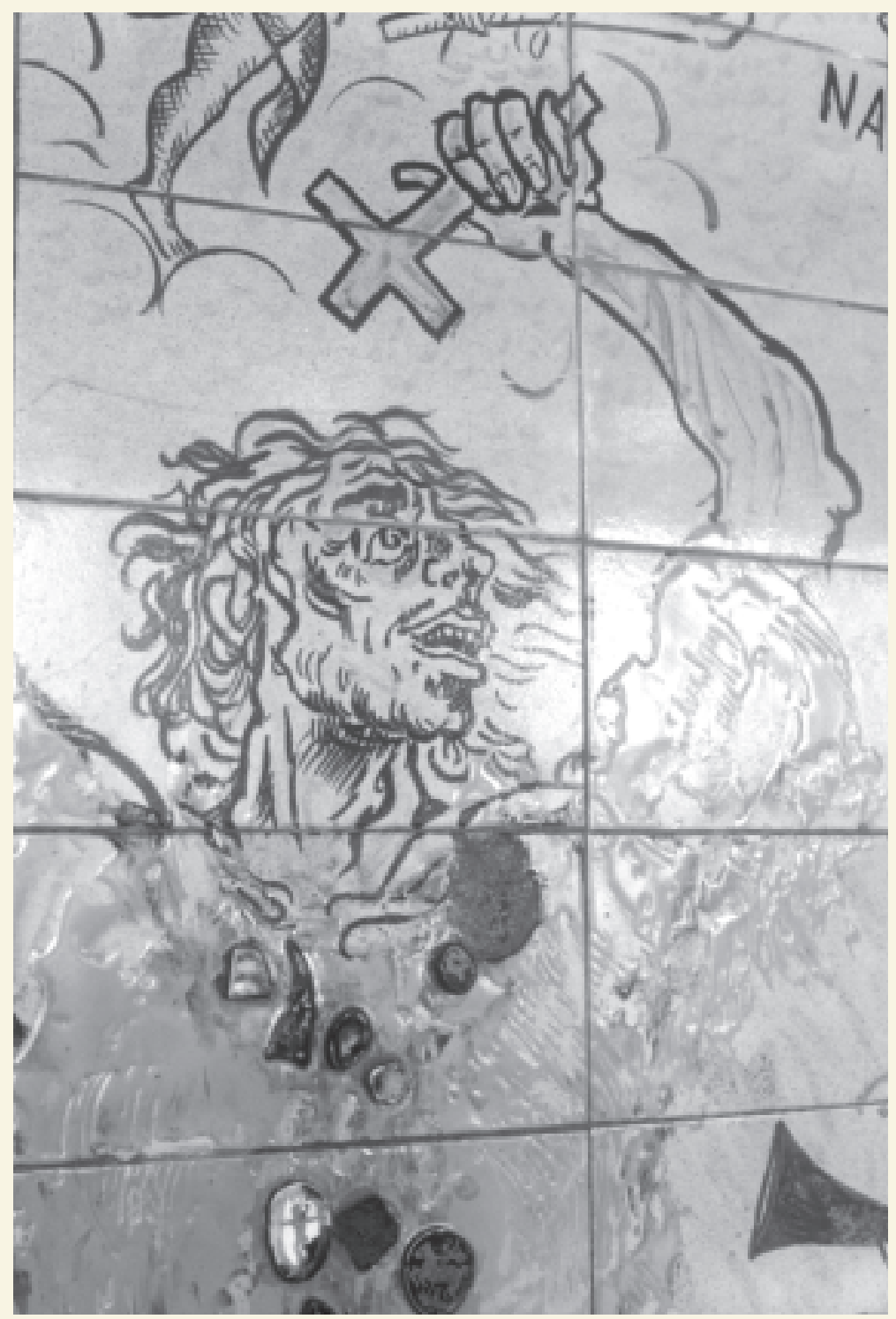




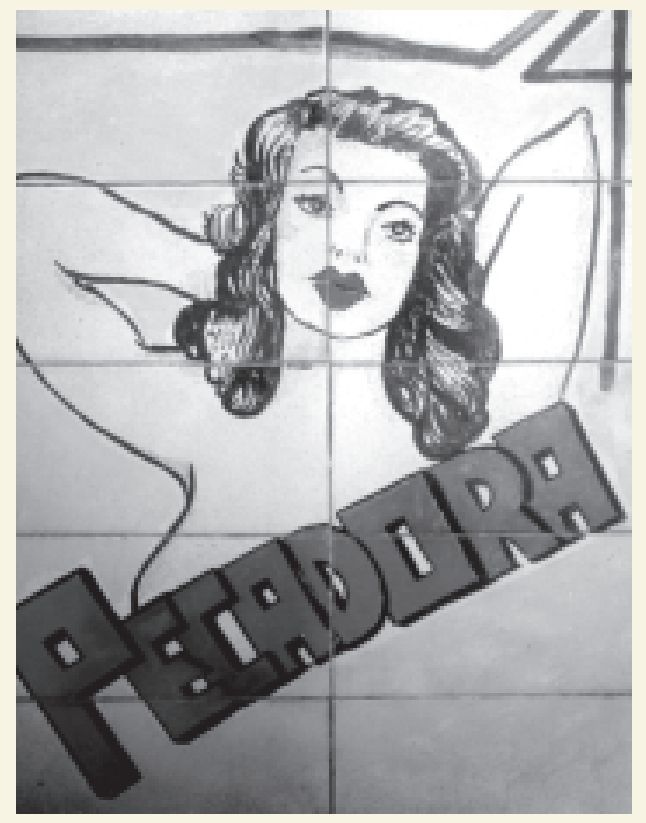

SIGO O ANÚNCIO E VEJO

Homem do seu tempo, que sente os influxos cada vez mais fortes das mídias comerciais, Lênio Braga (que também era designer gráfico) dedica relevante espaço do seu mural às sedutoras mensagens comerciais dirigidas sobretudo ao gosto popular. Além das mensagens que vendem mercadorias e sonhos, circulam pelo mural frases de pára-lamas de caminhão e ditos populares, que trocam sabedoria, espiritualidade e humor.
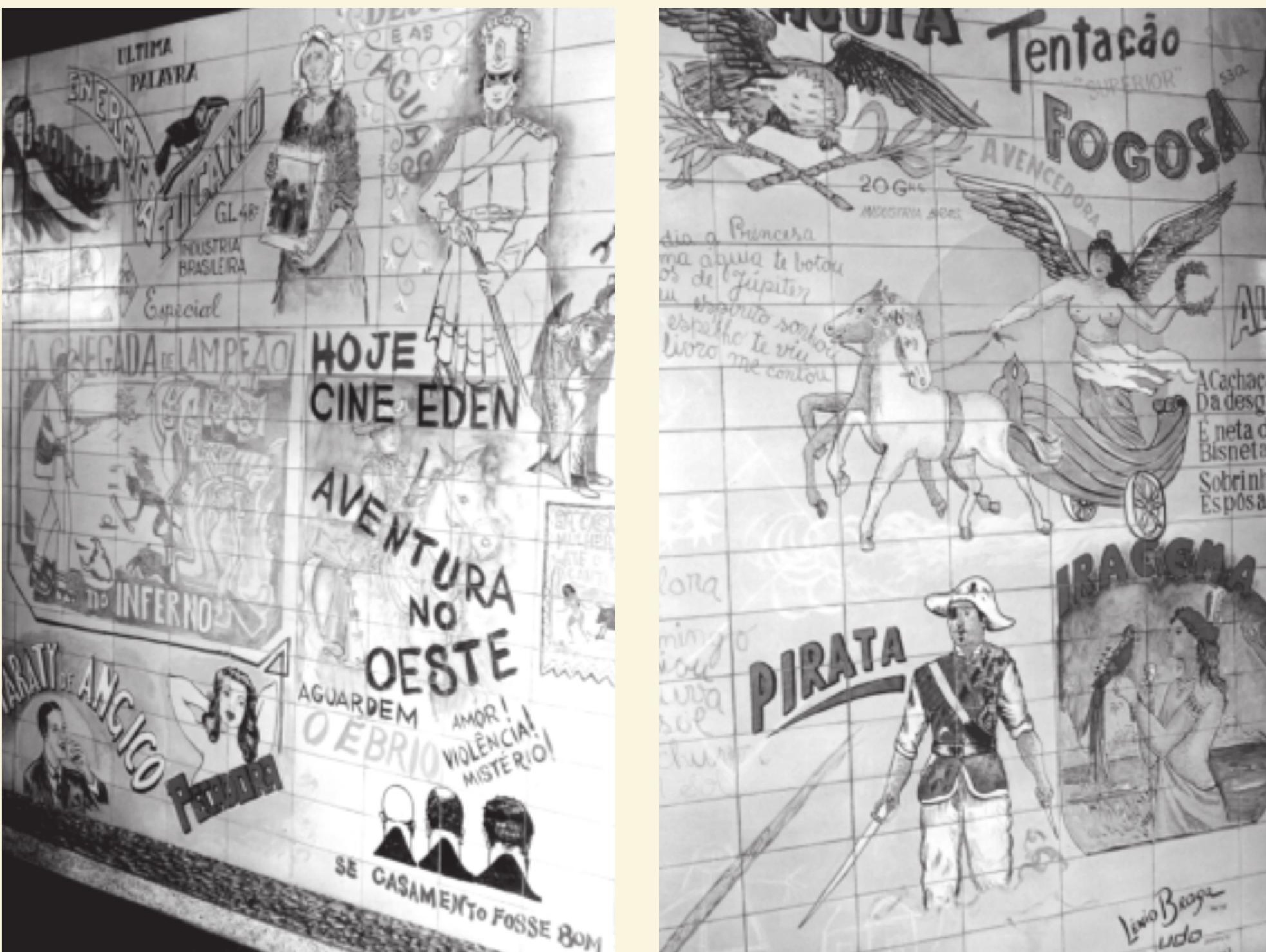


\section{CRENÇAS E PEÇAS DOPULARES}

Boi Mandingueiro, Trevo, Ferradura, Sexta-Feira 13, Saci-Pererê, Mula-Sem-Cabeça, "Vaca Lubisome", Ex-Votos, figuras monstruosas e outras relíquias do imaginário popular ganham brilho no painel de Lênio Braga. Noutra face do imaginário, o artista flagra o universo dos folguedos populares e das brincadeiras infantis do interior, compondo aí um dos espaços mais líricos do seu mural. A realidade, mesma, também tem seus assombros poéticos nos incontáveis sertões.
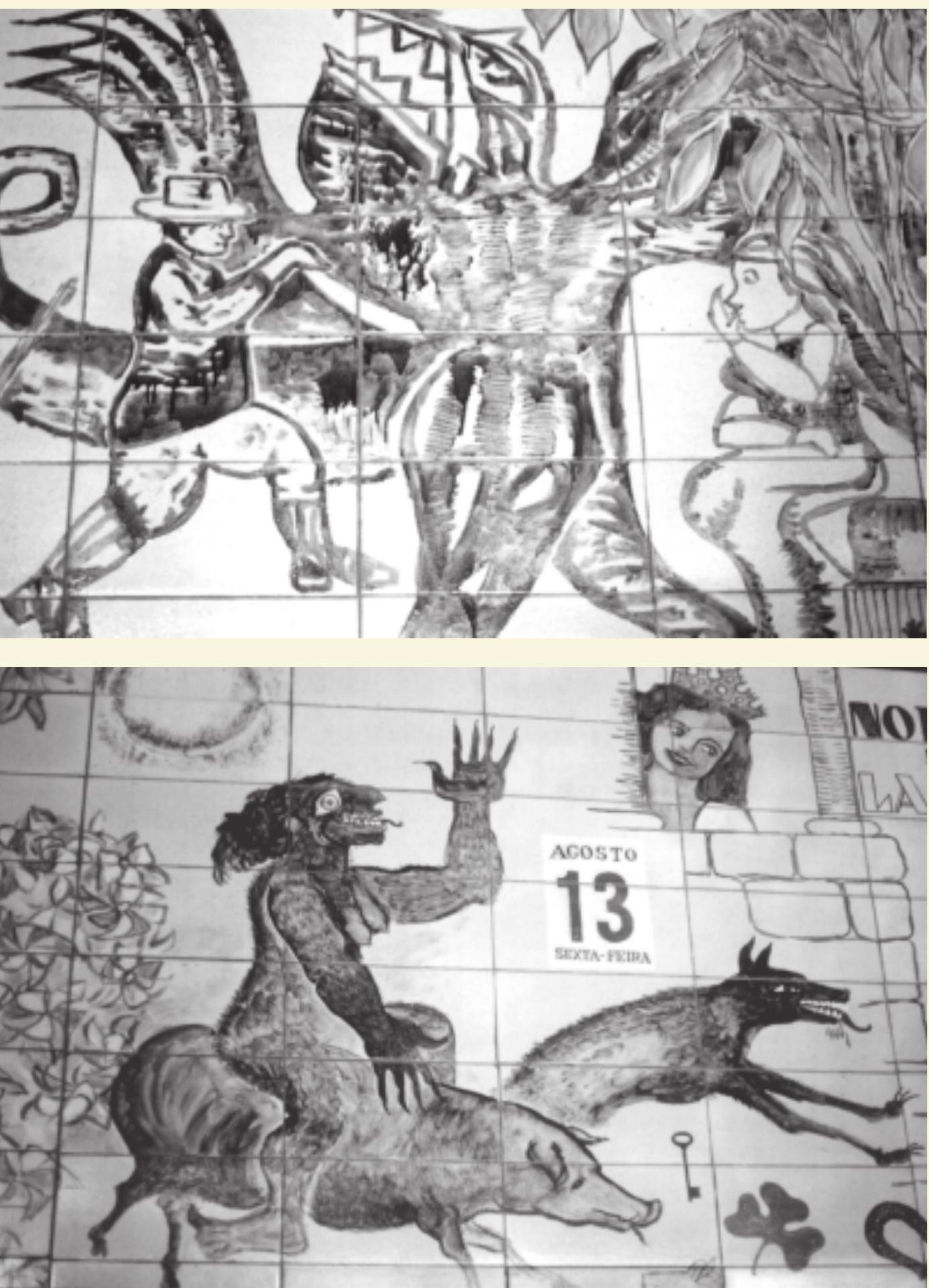

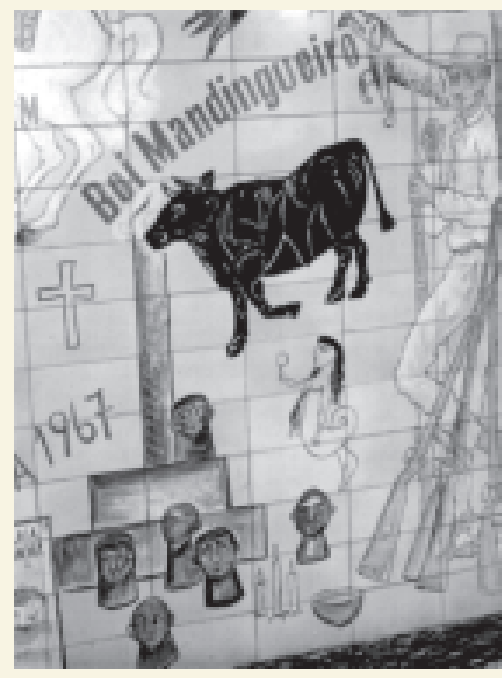

Rubens Edson Alves Pereira é Professor Adjunto da Universidade Estadual de Feira de Santana. Graduado em Letras pela UEFS, Mestre em Literatura Brasileira pela UFPB, Doutor em Literaturas de Língua Portuguesa pela PUC-Rio. Publicou, dentre outros livros: Fraturas do texto: Machado e seus leitores, 1999; Rotas e imagens: literatura e outras viagens (org.), 2000. É Coordenador do Programa de Pós-Graduação em Literatura e Diversidade Cultural da UEFS; criou e editou a revista Escrita (publicação dos alunos da pós-graduação da PUC-Rio), 1996/97; é editor de Légua \& meia: Revista de literatura e diversidade cultural. 